\title{
A Brief Review on the History, Methods and Applications of Plastination
}

\author{
Una Breve Reseña sobre la Historia, Métodos y Aplicaciones de la Plastinación
}

\author{
Shahyar Pashaei
}

PASHAEI, S. A brief review on the history, methods and applications of plastination. Int. J. Morphol., 28(4):1075-1079, 2010.

SUMMARY: Plastination is a process of preservation of anatomical specimens by a delicate method of forced impregnation with curable polymers like silicone, epoxy or polyester resins with vast applications in medical fields of study. Plastination is a technique of tissue preservation developed by Dr. Gunther von Hagens in 1977. In this process, water and lipids in biological tissues are replaced by curable polymers (silicone, epoxy, polyester) which are hardened, resulting in dry, odorless and durable specimens. In this technique it is possible for us to treat every part of the body and tissues to preserve it for educational purposes. Nowadays there are new and vast varieties of applications for plastination in the educational and cultural areas. This invention has been recognized as an artistic phenomena among many authors. This article will pay attention to the history, basic principles of methods and also various applications of the plastination during the brief period of its creation.

KEY WORDS: Plastination; Impregnation.

\section{INTRODUCTION}

Plastination is a technique of body tissue preservation with a great variety in its processes and development which is originally introduced to the medical world by Dr. Gunther von Hagens in 1977. In these processes, water and lipids in biological tissues are replaced by curable polymers mostly silicone, epoxy, and polyester which then will harden and finally result in natural looking, dry, odorless and durable specimens (von Hagens, 1986).

Many applications for plastinated tissues, organs and sections of bodies, prepared by the standard techniques of plastination, have been cited. Also they have been recognized as perfect tools for direct or indirect instructional purposes like teaching students. The materials for preparing the specimens are safe and hazardless like S10 silicone, S6 gas cure and S3 catalyst (Henry et al., 1997; von Hagens et al., 1987).

In recent years there is a growing tendency toward plastinated products. This growing tendency is reflected in articles which highlight the primary role and importance of the plastinated specimens as important educational, research and cultural tools in the medical world, although there are still arguments on the usefulness of these tools among anatomists (Jones \& Whitaker, 2009). At present, one may witness more profound effects of plastination in education with newer techniques of specimen processing like light plastination. The cost of resin is an important factor in original standard techniques of plastination procedures and also handling and mounting of heavy plastinated specimens is sometimes associated with limitations. Light plastination, is a cost effective method producing lightweight, rigid, goodquality and durable specimens and has facilitated work in this field (Steinke et al., 2008).

A brief look at history and events. Plastination is a technique invented by Gunther von Hagens in 1977, initially as part of his work as a scientific assistant at the Anatomical Institute of Heidelberg University. At first he was seeking a method to improve the quality of renal specimens in the laboratory so he began to experiment with a variety of plastics and finally after a great deal of trial and error on 
many tissues and organs, the basics of plastination method as we know today was born. The next step could be patenting of the plastination techniques which occurred and then he established his own company namely BIODUR, to promote his works further and provide the wide variety of specimens and chemical agents through one supplier. In 1986, the International Society for Plastination was founded and only after one year the Journal of the International Society for Plastination published. Some years later, Von Hagens established a specific organization at Heidelberg in 1993, namely Institute for Plastination. In 1995 by an invitation from the Japanese Anatomical Society he participated in an exhibition at the National Science Museum in Tokyo. This was the threshold of a series of exhibitions throughout the world by him and the first Body Worlds exhibition in Germany set up in Mannheim in 1997. While these developments were associated with so many positive aspects and attitudes toward the technique and its development, there were always some negative aspects within the confines of an academic institution. Von Hagens remained at Heidelberg University in various positions for about 20 years, but eventually left in 1997 on account of growing controversy and a lack of official recognition within Germany of the Institute for Plastination as a research institute. At that time he moved to Dalian Medical University in China as a guest professor (Jones \& Whitaker).

The unique specifications of Body Worlds exhibitions could be categorized in two types of plastinates therein. The first type is familiar to all anatomists as dissected body regions illustrating the basic anatomical and physiological functions of the various body systems. Also in these types of specimens one may find cross sections of the body display bones, muscles, organs, and vessels in precise and accurate detail, and specimens such as a smoker's lung demonstrate the effects of disease processes.

The other type of specimens tries to bring out a dead body from its dead or spiritless. Here someone may have a sense of vivid appearance and it is evident that the intention has been to get away from presenting dead bodies in their "deadness". The later exhibitions are designed to be less about dead bodies and more about the dynamic and living body. This move has had the effect of giving to the dead plastinates a welcoming, almost life-like visage, hence it becomes far easier to empathize with them and recognize them as "one of us." This is accentuated by the serene facial expressions, in these specimens (Boyde et al., 2002).

Plastination process at a glance. The basics of plastination techniques are the same in all varieties with few changes and specifications through different specimens. The process of plastination of whole-body slices actually starts with the proper choice of corpses. Preferably one may choose the shortest possible postmortem interval (2 to 10 days) is desirable because of the autolytic degeneration of delicate tissues. On the other hand each age category of dead bodies would be suitable for specific purposes and for normal tissue demonstrations it is better than the body be of average stature and weight and free of any deformity that would affect the morphology of the sections (Lischka, 1984).

In the classic technique the next step in the process of selected bodies or body parts is the embalm stage. Whole corpses are injected with 15-20 liters of Kaiserling-I solution, using an irrigator system with approximately $160 \mathrm{~cm}$ water column. Kaiserling-I solution consisting of $200 \mathrm{ml}$ formalin, $15 \mathrm{~g}$ potassium nitrate, $30 \mathrm{~g}$ potassium acetate and $1000 \mathrm{ml}$ deionized water (Henry et al.; Lischka et al., 1981).

Embalmed cadavers at this stage transferred to a tank for long-term storage. In contrast to those stored for dissection, bodies to be sectioned are kept floating in Kaiserling-I solution. In classical method before a cadaver is frozen, sectioning lines are drawn. Sections of the head (cross, coronal or sagittal) are marked at 1 to $2 \mathrm{~cm}$. Crosssections of the trunk and limbs are marked at $4 \mathrm{~cm}$. The body is then transferred to a deep-freezer where it remains at $-25^{\circ} \mathrm{C}$ for several days. As sections are produced, they are immediately submerged (at room temperature) in plastic containers filled with $80 \%$ ethanol. Once thawed, sections are carefully cleaned of any defilement. Loose pieces of intestine are sutured and pinned in place. Using compressed air, vessels and other cavities are cleaned of all detritus (Lischka; Kessler, 1990).

The sections dehydrated by freeze substitution using acetone of a grade between 96 and $100 \%$ purity. There should always be enough acetone in the dehydrating vessels so that the section closest to the surface does not become dry. Transfer of sections from one bath to the next should be done quickly and gloves should always be worn to prevent skin injury. It is also advisable to wear a gas mask. Dehydration is complete when the water concentration stabilizes at $1 \%$ or less. To accomplish degreasing, one may use another step of immersing the sections in methylenechloride at room temperature (Lischka; Kessler).

There are so many resins and materials for completing this step. For example both Biodur S 10 and Biodur PEM 27 are used for plastination of body sections. The usage of $\mathrm{S} 10$ (silicone rubber) is sometimes limited to specimens of the brain tissue, isolated or in situ and also specimens to be used by students for self-instruction. PEM 27 is the choice for all specimens requiring good visual 
appearance with clear surface detail. Forced impregnation is carried out according to recommendations in the Heidelberg Plastination Folder - 1985, a publication obtained from Dr Gunther Von Hagens of the Institute of Anatomy, University of Heidelberg. A reaction mixture of PEM 27 and E 6 (hardener) is used. Impregnated specimens are wiped free of excess resin and placed in an oven at $40^{\circ} \mathrm{C}$ where they remain for $4-5$ weeks. Curing is complete when the specimens are thoroughly dry (Lischka et al.; Kessler; Bickley, 1984).

Cured specimens are stored until a large enough number has accumulated for grinding. Sections are polished on a wet grinder until cut surfaces are smooth. By grinding the surfaces in this manner it is possible to demonstrate specific structures such as the median atlanto-axial joint, showing the transverse atlantic ligament. Grinding is not a popular step because it is accompanied by an impressive amount of noise and dirt. Polymerized resin on the lateral and inner surfaces is removed with the help of drilling devices. So far, six totally sectioned bodies have been prepared in this way. Proper storage and access to specimens is dependent on a complete inventory system including labeling and order sheets for usage (Lischka).

To increase the quality of specimen usefulness, specific anatomic structures shown on the specimen should be noted. Sections are usually stacked in cardboard boxes, prominently marked with the index numbers of the specimens they contain. There are also some specific techniques of brain plastination namely P 35 and P40 techniques (Lischka; Bickley; Weiglein, 1996). It includes preparing stage of head and the embalming fluid consisted of $500 \mathrm{ml}$ ethanol $96 \%, 1000 \mathrm{ml}$ formalin $40 \%, 25 \mathrm{ml}$ phenol liquefied $80 \%, 300 \mathrm{~g}$ sodium chloride, $300 \mathrm{~g}$ chloral hydrate and $300 \mathrm{ml}$ glycerin in 10 liters of water. The head was removed from the body and rinsed in running tap water for two days (de Boer-van Huizen et al., 1992). The P 35 technique gives excellent differentiation between grey and white matter of the brain. Macrosections of the head allow the study of the brain and its surrounding structures, i.e., the brain in situ. Although the process of plastination is time-consuming, the availability of dry, odorless and durable specimens of the human head provides reference material for pre and post doctoral training in cross sectional anatomy which is convenient to handle (Weiglein; de Boervan Huizen et al.).

Two widely used polymers have been used, P35 and P40. P35 was introduced first and yielded brain slices of unparalleled beauty, clarity and definition of white and gray matter. P40 was introduced 10 years later and is a shorter and less cumbersome technique. It also yields a remarkable differentiation of white and gray matter. However, the P40 polymer has a specific problem when used on brain tissue, orange spots in the gray matter and when uniformly distributed throughout the gray matter, it may resemble the coloration of P35 slices (Henry, 2004).

Sheet plastination has proven to be a vital tool in the enhancement and clarification of anatomical concepts and relationships previously often difficult to appreciate. Sheet plastination is a means in which thin slices of organs, extremities, brain or even whole in situ sections may be specially processed and encapsulated within a clear, smooth resin sheet. Sections may vary in thickness from $2 \mathrm{~mm}$ to $6 \mathrm{~mm}$ depending upon the region, type of tissue and the desired result (Cook, 2005).

Applications and advantages. Plastination is a combination of science, technological phenomenon and artistic events in association with cultural aspects of life and death. Deep analysis of the artistic and cultural exhibitions of Von Hagens all around the world may appear at first sight as a similar and integral exhibition, but this would be a simplistic view on a very complex and huge mass of cultural aspects hidden through them. For example the original exhibition, now referred to as Body Worlds 1, consisted mainly of what would now be regarded as relatively static and lifeless exhibits that struck some viewers as disturbing and frightening (Weiss, 2007). Compared to the original exhibition, Body Worlds 2 is described as "more exhilarating and dynamic" (Institute for Plastination, 2009), In contrast, Body Worlds 3 is "a return to the Renaissance." They have also emphasized different facets of human anatomy: the brain (Body Worlds 2), the heart (Body Worlds 3), and development and ageing (Body Worlds 4). It is evident that the intention has been to get away from presenting dead bodies in their "deadness" (Skulstad, 2007). The later exhibitions are designed to be less about dead bodies and more about the dynamic and living body. This aspect of exhibitions afforded new span and capacities to such gatherings and made it far easier for visitors to feel so close to the specimens and even accepted them as "one nearly vivid human being."

According to some authors the whole-body plastinates can be divided into four broad categories, the first grouping comprises the "sporting" plastinates: those engaged in physical activity, which encompasses those plastinates whose exceptional dissections reveal anatomy in a spectacular way. The third Category encompasses historical plastinates that mimic poses, familiar from the Renaissance anatomy artists. Finally, The plastinates in fourth category are more different and have divergence with all other aforementioned plastinates (Jones \& Whitaker). 
At present, plastination has established itself as an indispensable contributor to the teaching armamentarium of clinical anatomists (Jones, 2002; Reidenberg \& Laitman, 2002). Teachers have accepted plastinated human specimens as superior specimens in relation to synthetic models, on account of their ability to reflect anatomical variations. Plastinated specimens also can be conveniently stored (Latorre et al., 2007).

At present time plastination products not only as a training tool but also as a research mean are increasingly appreciated throughout medical schools. The potential of plastination lies in its ability to preserve delicate structures and their interconnections, enabling them to be traced microscopically (Jones). Even ultrathin plastinated slices can be obtained and have been used to construct precise three-dimensional computer models of anatomical structures (Sora et al., 2007). To date, plastination techniques are featured in studies of anatomical organization in the female urethra (Fritsch et al., 2006), esophageal muscles (Wang et al., 2007), the carpal tunnel (Sora \& Genser-Strobl, 2005), and skin ligaments (Nash et al., 2004). Their great advantage over traditional histology techniques lies in the ease with which it is possible to move between the macroscopic and the microscopic. However, it appears that many anatomists have not yet realized the revolutionary significance of plastination for anatomical research.

In one survey most exhibition visitors claimed to be considerably better informed about their own bodies, although less than half intended to pay better attention to their future physical health (Leiberich et al., 2006). Myser (2007) draws a distinction between von Hagens "formal Body Worlds curriculum (e.g., education) and his possible Body Worlds hidden curricula (e.g., art, entertainment, showmanship, personal and professional self-actualization or selfaggrandizement, reaping financial rewards)." However, this tension is not uncommon. As Youngner points out, education, art, and money-making have never been successfully compartmentalized in museums (Youngner, 2007).

Plastination seems to have a great future in all fields of training, research and also public culture and instruction throughout the world. New fast and hazardless techniques make it available to many departments of anatomy. Cheaper costs and also vivid appearance of the specimens make the plastination a unique window to the world of anatomy for learners.

PASHAEI, S. Una breve reseña sobre la historia, métodos y aplicaciones de la plastinación.Int. J. Morphol., 28(4):1075-1079, 2010.

RESUMEN: La plastinación es un proceso de conservación de muestras anatómicas mediante un método delicado de impregnación forzada con polímeros curables como la silicona, resinas de poliéster o epóxicas, con vastas aplicaciones en el campo del estudio de la medicina. La plastinación es una técnica de conservación de tejidos desarrollados por el Dr. Gunther von Hagens en 1977. En este proceso, el agua y los lípidos en los tejidos biológicos se sustituyen por polímeros curables (silicona, epoxi, poliéster), que se endurecen, lo que resulta en un especimen seco, sin olor y duradero. En esta técnica, es posible tratar todos los tejidos y partes del cuerpo, a fin de preservarlo para fines educativos. Actualmente tenemos una amplia gama de solicitudes de plastinación incluyendo: docentes, culturales, y también, hoy en día, esta invención ha sido reconocida como un fenómeno artístico por muchos autores. En este artículo se hace un relato histórico de los principios básicos del método y las diversas aplicaciones de la plastinación en su breve periodo de creación.

PALABRAS CLAVE: Plastinación; Impregnación.

\section{REFERENCES}

Bickley, H. C. Plastination: A new technique for anatomic pathology and forensic science. Pathol. Update Series, 2(16):2-8, 1984

Boyde, A.; Fraher, J. P.; Morris, J. F.; Moxham, B. J.; Bennett, J. P.; Newell, R.; Soames, R. W. \& Dangerfield, P. Dissections in display. Independent, 16 March:2, 2002.

Cook, P. Epoxy and Polyester Sheet Plastination. Ohrid, $8^{\text {th }}$ Interim Conference on Plastination, 2005. de Boer-van Huizen, R. T.; Cornelissen, C. J. \& ten Donkelaar, H. J. Sheet plastination of the human head. J. Int. Soc. Plastination, 6:20-4, 1992.

Fritsch, H.; Pinggera, G. M.; Lienemann, A.; Mitterberger, M.; Bartsch, G. \& Strasser, H. What are the supportive structures of the female urethra? Neurourol. Urodyn., 25:128-34, 2006.

Henry, R. W. Polyester plastination techniques, specific 
troubles and problems. Murcia, Spain, $12^{\text {th }}$ International Conference on Plastination, 2004.

Henry, W. R.; Janick, L. \& Henry, C. Specimen preparation for silicone plastination. J. Int. Soc. Plastination, 12(1):13-7, 1997.

Institute for Plastination. Questions and answers. Avalaible in: http://www.bodyworlds.com/en/exhibitions/ questions_answers/, 2009.

Jones, D. G. Re-inventing anatomy: the impact of plastination on how we see the human body. Clin. Anat., 15(6):436-40, 2002.

Jones, D. G. \& Whitaker, M. I. Engaging with plastination and the Body Worlds phenomenon: A cultural and intellectual challenge for anatomists. Clin. Anat., 22:7706, 2009.

Kessler, R. Fixation solutions for color preservation in plastination. J. Int. Soc. Plastination, 4:9, 1990.

Latorre, R. M.; Garcia-Sanz, M. P.; Moreno, M.; Hernández, F.; Gil, F.; López, O.; Ayala, M. D.; Ramírez, G.; Vázquez, J. M.; Arencibia, A. \& Henry, R. W. How useful is plastination in learning anatomy? J. Vet. Med. Educ., 34:172-6, 2007.

Leiberich, P.; Loew, T.; Tritt, K.; Lahmann, C. \& Nickel, M. Body Worlds exhibition-Visitor attitudes and emotions. Ann. Anat., 188:567-73, 2006.

Lischka M. Plastination of Whole-Body Slices with Polymerizing Emolusions. Vienna, Institute of Anatomy, The University of Vienna Waehringerstrasse, 1984.

Lischka, M. F.; Krammer, E. B.; Egger, T. P.; Paolini, H, Zur Praparategualitat von anatomischen Studienleichen: reier Rezepturen mit der Vergleich verschiedener phenolfklassischen Phenol-Formalin-Methode. Anat. Anz., 150:226-34, 1981.

Nash, L. G.; Phillips, M. N.; Nicholson, H.; Barnett, R. \& Zhang, M. Skin ligaments: Regional distribution and variation in morphology. Clin. Anat., 17:287-93, 2004.

Myser, C. Taking public education seriously: BODY WORLDS, the science museum, and democratizing bioethics education. Am. J. Bioeth., 7:34-6, 2007.

Reidenberg, J. S. \& Laitman, J. T. The new face of gross anatomy. Anat. Rec., 269(2):81-8, 2002.
Skulstad, K. Body Worlds draws large crowds-and controversy. Avalaible in:http://www. canadianchristianity.com/cgi-bin/bc.cgi?bc/bccn/1106/ 18body/, 2007.

Sora, M. C. \& Genser-Strobl, B. The sectional anatomy of the carpal tunnel and its related neurovascular structures studied by using plastination. Eur. J. Neurol., 12:380-4, 2005.

Sora, M. C.; Genser-Strobl, B.; Radu, J. \& Lozanoff, S. Three-dimensional reconstruction of the ankle by means of ultrathin slice plastination. Clin. Anat., 20:196-200, 2007.

Steinke, H.; Rabi, S.; Saito, T.; Sawutti, A.; Miyaki, T.; Itoh, M. \& Spanel-Borowski, K. Light-weight plastination. Ann. Anat., 190(5):428-31, 2008.

von Hagens, G. Heidelberg plastination folder. Collection of all technical leaflets for plastination. $2^{\text {nd }}$ Edn. Heidelberg, Anatomische Institut, Universität Heidelberg, 1986.

von Hagens, G.; Tiedemann, K. \& Kriz, W. The current potential of plastination. Anat. Embryol., 175:411-21, 1987.

Wang, Q.; Xu, S.; Tu, L.; Liu, Y. \& Zhang, M. Anatomic continuity of longitudinal pharyngeal and esophageal muscles. Laryngoscope, 117:282-7, 2007.

Weiglein, A. Plastination of brain slices. J. Int. Soc. Plastination., 11:34, 1996.

Weiss, J. Looking death in the face. The Dallas Morning News, Avalaible in: http://www.guidelive.com/ sharedcontent/, 2007.

Youngner, S. J. The stakes are not very high in this game. Am. J. Bioeth., 7:42-3, 2007.

\section{Correspondence to:}

Shahyar Pashaei

Department of Medical Sciences

Great Persian Encyclopedia Foundation

Ministry of Research, Science and Technology

Tehran

IRAN

Email: Dr-pashaei@bdbf.org.ir

Received: 24-04-2010

Accepted: 26-09-2010 
